\title{
Aromatase and Sex Steroid Receptors in Human Vena Cava
}

\author{
Hironobu SASANO*, Hiroshi MURAKAMI*,**, SoIchirou SHIZAWA*, SUSUMU SATOMI**, \\ HIROSHI NAGURA* AND NoBUHIRo HARADA*** \\ * Department of Pathology, Tohoku University School of Medicine, Sendai, Japan \\ ** Department of Surgery, Tohoku University School of Medicine, Sendai, Japan \\ *** Division of Molecular Genetics, Institute for Comprehensive-Medical Science, Fujita Health University, Toyoake, Japan
}

\begin{abstract}
Among sex steroids, especially estrogen metabolism has been considered to play a role in the function and pathology of human veins. We investigated the expression and activity of the estrogen-producing enzyme aromatase and estrogen receptor (ER) in human vena cava to assess possible in situ biosynthesis of estrogens and their modes of action. We first examined aromatase expression by immunohistochemistry in human inferior vena cava obtained from 29 autopsy cases (11 males, 18 females, 63.6 13.0 years old). We then semiquantitated the level of aromatase mRNA by reverse transcriptase-polymerase chain reaction in 24 cases and aromatase activity by ${ }^{3} \mathrm{H}$-water assay in 15 cases to examine whether or not and in which cell types aromatase was expressed. We also studied alternative use of multiple exon $1 \mathrm{~s}$ of its gene and immunolocalization of $17 \beta$-hydroxysteroid dehydrogenase type I (17 $\beta$-HSD I), which converts estrone produced by aromatase to estradiol, a biologically active estrogen and ER. Aromatase and $17 \beta$-HSD I immunoreactivity were both detected in smooth muscle cells (SMC) of the media in all the cases and in endothelial cells (EC) in 20 and 22 cases, respectively. ER immunoreactivity was detected in SMC of vena cava in 21 cases. The amount of aromatase mRNA was significantly greater in the cases utilizing 1c (I.3) or $1 \mathrm{~d}$ (P.II) of exon 1 (9 cases, $191.1 \pm 26.3$ attomol/ng total RNA) than those utilizing $1 \mathrm{~b}$ (I.4) as the promoter (14 cases, 50.6 \pm 13.0 attomol/ng total RNA) $(\mathrm{p}<0.01)$. Significant correlation $(\mathrm{p}<0.05)$ was observed between the amount of aromatase mRNA and aromatase activity in 15 cases examined. No significant correlation was detected between the amount of aromatase mRNA or aromatase labeling index and the ER status. These results suggest that estrone and estradiol are produced in the human vena cava and that their production is mediated by aromatase and 17 $\beta$-HSD I, respectively but not all of these locally synthesized estrogens may not work directly in situ.
\end{abstract}

Key words: Vein, Estrogen, Aromatase, Receptor, Human

(Endocrine Journal 46: 233-242, 1999)

VARIOUS clinical and epidemiological observations suggest that sex steroids play an important role in the function and pathology of human veins [1-3]. Karas et al. recently demonstrated the presence of estrogen receptor (ER) in smooth muscle cells cultured from surgical specimens of non-pathological human saphenous veins removed for coronary artery bypass surgery [4]. Perrot-Applanat et al. also demonstrated the presence of progesterone receptor (PR) in

Received: June 22, 1998

Accepted: January 5, 1999

Correspondence to: Hironobu SASANO, M.D. Department of Pathology, Tohoku University School of Medicine, 2-1 Seiryou-machi, Aoba-ku, Sendai 980-8575, Japan varicose saphenous veins from both males and females. These results indicate that sex steroids may act directly on human veins, as reported in human coronary [5] and uterine arteries [6].

In postmenopausal women and men, estrogen biosynthesis is mainly peripheral, through conversion of androstenedione or $\mathrm{C} 19$ steroids from the adrenal cortex, ovary and/or testis [7]. This conversion is catalyzed by the enzyme complex cytochrome P450 aromatase. In humans, aromatase has been detected in numerous extragonadal tissues including adipocytes [8], skin fibroblasts [9], liver [10], brain [11], bone [12] and various sex steroid-dependent neoplasms $[13,14,15]$. These estrogens derived from the local aromatization have been postulated to exert 
estrogenic actions on these tissues. Especially in sex-steroid dependent neoplasms, increased aromatase expression and/or activity in the tumor tissue has been demonstrated to closely correlate with malignant phenotype despite the fact that increased serum estrogen concentration has not been demonstrated in women with these tumors. In vascular tissues, aromatase activity has been demonstrated in cultured rat aortic endothelial cells (ECs) [17] and bovine aortic smooth muscle cells (SMCs) [18] but not in human vascular systems. In addition, localization of aromatase expression has not been studied in any species. Recently, alternative splicing of multiple forms of exon 1 has been demonstrated to contribute to the tissue-specific expression of aromatase $[16,19]$. In addition, a frequent switching of tissue-specific exon $1 \mathrm{~s}$ from exon $1 \mathrm{~b}$ or $\mathrm{I} .4$ to $1 \mathrm{c}$ or I. 3 has been demonstrated for transcripts found in adipose tissues taken from breast cancer patients. This switching has been considered to result in overproduction of estrogens in situ and the subsequent proliferation of estrogen-dependent breast cancer cells [20, 21]. It therefore becomes very important to study the expression of aromatase and ER in situ, examine the utilization of exon 1s of aromatase and to correlate these findings in human veins, in order to understand the possible roles and biological significance of in situ estrogen production and possible direct effects of estrogen in the human vein.

Therefore, in this study we immunolocalized aromatase, semiquantitated the amount of aromatase mRNA by reverse transcriptase-polymerase chain reaction (RT-PCR), and examined alternative splicing of multiple exons 1 in 29 cases of normal human vena cava obtained at autopsy. We also studied aromatase activity by ${ }^{3} \mathrm{H}$-water assay in 15 cases and immunolocalized ER and type I 17 beta-hydroxysteroid dehydrogenase (17 $\beta$-HSD I), which converts estrone (E1), the major product of aromatase, to estradiol (E2) [22], a potent estrogen.

\section{Materials and Methods}

\section{Specimens}

Human inferior vena cava were collected at autopsy performed within 4 hours postmortem from 29 subjects (male 11, female 18, 15-88 years, mean
63.6 \pm 3.0 year old). None of the deceased had severe liver dysfunction and/or had been under long term steroid therapy. All the specimens were immediately and carefully dissected in order to remove surrounding adipose tissues. Specimens for immunohistochemical studies were fixed in 4\% paraformaldehyde adjusted to $\mathrm{pH} 7.4$ for 12 to 16 hours at room temperature, and embedded in paraffin. 24 specimens were available for RT-PCR studies and portions of these specimens were immediately frozen in liquid nitrogen and stored at $-80^{\circ} \mathrm{C}$ until use. The protocol for this investigation was approved by the Medical Ethics Committee of Tohoku University School of Medicine, Sendai, Japan.

All the specimens were stained with hematoxylineosin and modified Masson Goldner's method and demonstrated no significant histopathological abnormalities.

\section{Antibodies}

Rabbit anti-aromatase IgG was prepared against the enzyme purified from human placenta. Preparation and characterization of the antibody were previously described elsewhere [23]. Antibody to $17 \beta$-HSD I was generated in rabbits with human placental protein as the antigen [24], and was kindly provided by Drs. Matti Poutanen and Reijo Vihko, Department of Clinical Chemistry, University of Oulu, Oulu, Finland. Monoclonal antibody against ER was purchased from Immunotech SA (Luminy, France). Monoclonal antibody to ER recognizes $\mathrm{ER} \alpha$ but not $\mathrm{ER} \beta$. To characterize immunopositive cells, we used monoclonal antibodies to human $\alpha$ smooth muscle actin ( $\alpha$-SMA) for smooth muscle cells, and CD34 antigen for endothelial cells in adjacent tissue sections. All these monoclonal antibodies were purchased from DAKO Co. Ltd. (Copenhagen, Denmark).

\section{Immunohistochemistry}

Details of immunohistochemical procedures were previously reported by the authors $[13,25,26]$. Immunohistochemical staining was carried out by a biotin-streptavidin method with the Histofine immunostaining system (Nichirei Co. Ltd., Tokyo, Japan). For ER immunohistochemistry, the 
deparaffinized sections were autoclaved for antigen retrieval, and a catalytic signal amplification method (DAKO) was employed to enhance the sensitivity of detection. Without autoclave treatment, ER immunoreactivity could not be demonstrated. ER immunoreactivity could not be demonstrated without employing a catalyzed signal amplification method. Negative control sections were incubated with nonimmune rabbit serum for aromatase and $17 \beta$ HSD I and with $0.01 \mathrm{~mol} / \mathrm{L}$ PBS or nonimmune mouse IgG for ER. No immunoreactive products were observed in these negative control sections. Positive immunostain control sections are as follows: full-term placenta for aromatase and $17 \beta$-HSD I and proliferative endometrium for ER.

\section{Semiquantitaion of immunoreactivity}

We examined tissue sections under a light microscope and determined the labeling index as the ratio of positive vascular wall cells in order to semiquantitate immunoreactivity. The immunostained slides were independently reviewed by two of the authors (H. Murakami and H. Sasano). Based on the percentage of cells that stained positive for aromatase, tissue slides were classified into four groups: -) none, 1) 1 to $5 \%$, 2) 5 to $25 \%, 3) 25 \%$, according to the report of Watanabe et al. [27] with some modification. Disconcordant cases reported by these two investigators were re-evaluated simultaneously by Murakami and Sasano by means of double light microscopy.

\section{Quantitative Analysis of Aromatase mRNA by PCR}

The methods have been previously described by the authors $[14,15,28]$. Briefly, samples were homogenized in 5 volumes of $5 \mathrm{~mol} / \mathrm{L}$ guanidine thiocyanate containing $5 \mathrm{mmol} / \mathrm{L}$ sodium citrate and $0.5 \%$ sodium sarcosyl. The total RNA fraction from all homogenates was prepared as described by Chirgwin et al. [29]. In all specimens examined, two distinctive bands corresponding to $28 \mathrm{~S}$ and $18 \mathrm{~S}$ of ribosomal RNA, were detected by running total RNA on an ethidium bromide stained agarose gel. In addition, a smear of mRNA was detected at 1 to $3 \mathrm{~Kb}$ in the gel. The measurement of aromatase mRNA in these samples was performed by RT-PCR with a specific sense primer labeled with a fluorescent dye and a specific antisense primer as previously described [15, 28]. The internal standard RNA used in the assays was synthesized in vitro from modified aromatase cDNA with 0.01 attomole of human aromatase RNA containing a 21-base insertion as an internal standard and amplified by PCR for 26 cycles with a fluorescent dye (FAM)-labeled primer. An FAM-labeled sense primer (5'-TACTACAACCGGGTATATGG-3') corresponding to the sequence in exon 3 and an antisense primer (5'-TGTTAGAGGTGTCCAGCATG-3') corresponding to the sequence in exon 5 were used in the PCR for quantitative analysis of aromatase mRNA. An aliquot $(4 \mu \mathrm{l})$ of the fluorescent PCR products was mixed with $3 \mu \mathrm{l}$ of GENESCAN-1000 ROX consisting of DNA size markers labeled with a fluorescent dye, ROX, and analyzed fluorometrically with a Gene Scanner 362 (Applied Biosystems). The FAM-labeled PCR products showed two peaks corresponding to PCR products of aromatase mRNA and the internal standard RNA at positions of approximately 378 and 399 $\mathrm{bp}$, respectively. These two peaks were designated AROM mRNA and standard RNA, respectively (Fig. 1A). The internal size standards gave five peaks of 262, 293, 317, 439 and 557 as shown in Fig. 1A. The amount of aromatase mRNA in the tissue RNA was calculated from the peak areas of fluorescent products by the internal standard as previously described [28]. No fluorescent products were detected without adding RNA.

\section{Utilization of Alternative Exons 1}

The utilization of alternative exons 1 of the aromatase gene was examined by RT-PCR of the RNA fraction with sense primers specific for exons 1b (I.4), 1c (I.3) and 1d (P.II) and the fluorescent dye-labeled antisense primer specific for exon 2 as described previously $[14,15,28]$. Harada et al. previously reported that exons 1a (I.1), 1b (I.4), 1c (I.3) and 1d (P.II) are utilized in aromatase expression in human placenta, skin fibroblasts and fetal liver, ovary, prostate and brain, respectively. Exon 1a was not examined in this study because exon 1a is utilized exclusively in human placenta [28]. Fluorescent PCR products were analyzed with a 362 Gene Scanner. The aromatase mRNAs transcribed from exons 1a (I.1), 1b (I.4), 1c (I.3) and1d (P.II) 


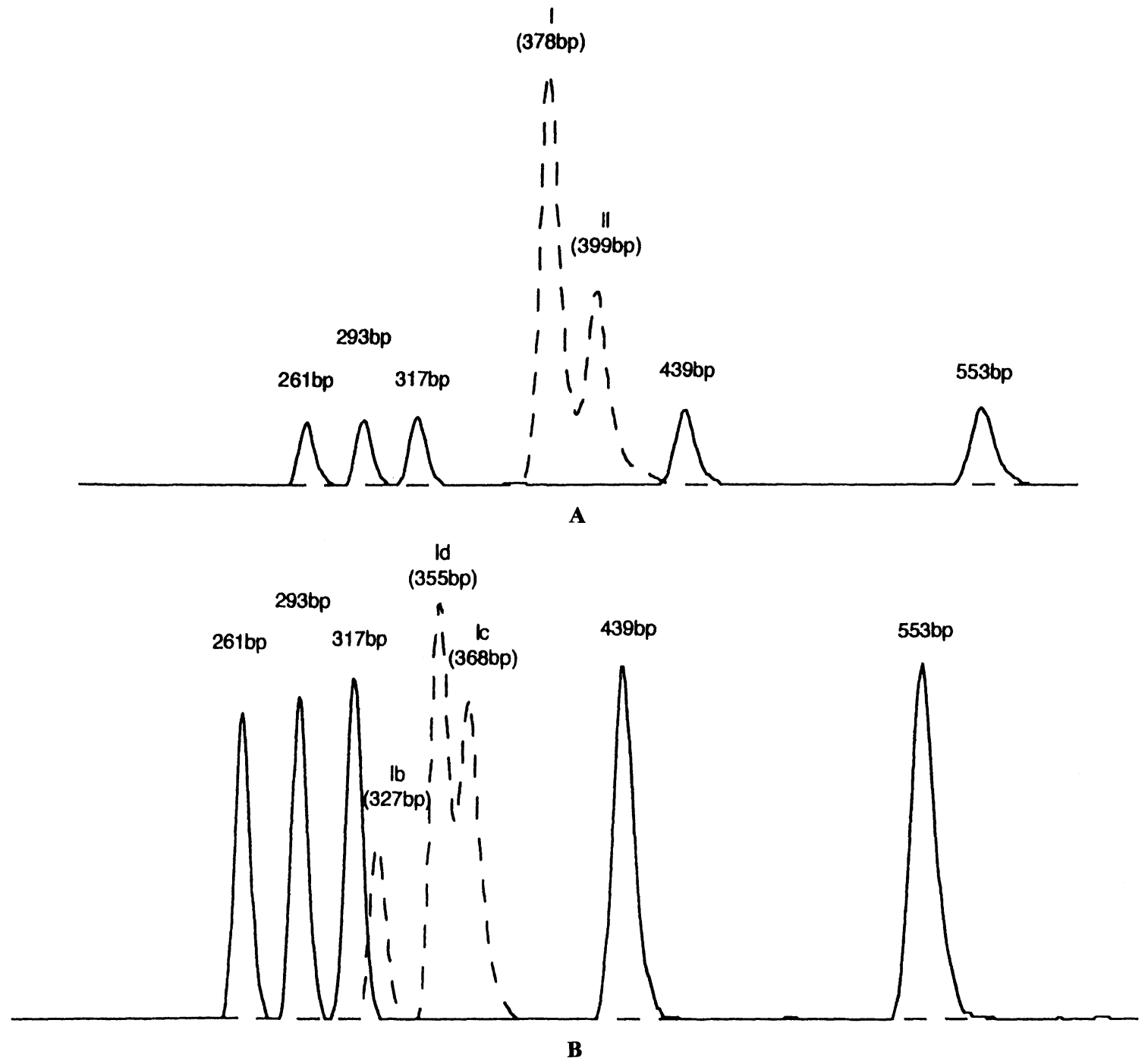

Fig. 1. An example of an analysis of a RT-PCR study of aromatase mRNA content (A) and utilization of alternative exon 1 (B) in inferior vena cava of case 9 in Table 1 (66-year-old female) by Gene Scanner 362. Peaks represent the Gene Scan 1000 ROX of the internal size standards, 261, 293, 317, 439 and 553 base pairs, respectively. (A) Peaks I and II represents PCR products of aromatase mRNA and the internal standard RNA at positions of 378 and 399 base pairs, respectively. In this case, mRNA content was calculated as $\mathbf{4 5 6 . 6}$ attomole per ng total RNA. (B) A major transcript of this case was exon 1d or P.II, which has a 355 bp (base pair) with a minor transcript of exon $1 \mathrm{~b}$ or I.4 (327 bp) and 1c or I.3 (368 bp)

yielded PCR products at positions corresponding to $402,327,368$ and $355 \mathrm{bp}$, respectively. The Genescan-1000 ROX was used as internal size standard as in quantitative analysis of aromatase mRNA (Fig. 1B).

\section{Aromatase activity}

Aromatase activity in human vena cava tissues was determined in 15 cases in which specimens were available according to the published method $[30,31]$ with modification. Microsomal fractions were prepared from vascular tissue homogenates by successive centrifugation as described [23] and suspended in $20 \mathrm{mmol} / \mathrm{L}$ Tris- $\mathrm{HCl}(\mathrm{pH} 7.5)$ containing $1 \mathrm{mmol} / \mathrm{L}$ EDTA, $10 \%$ glycerol, $5 \mathrm{mg} / \mathrm{ml}$ pepstatin and 5 $\mathrm{mg} / \mathrm{ml}$ leupeptin. The reaction mixture comprised $0.1-1 \mathrm{mg}$ of microsomal fraction, $5 \mathrm{mmol} / \mathrm{L} \mathrm{MgCl} 2$, $5 \mathrm{mmol} / \mathrm{L}$ glucose-6-phosphate, 5 units of glucose-6phosphate dehydrogenase, $2 \mathrm{mmol} / \mathrm{L}$ rotenone and 200 pmol of $1 \mathrm{~b}-\left[{ }^{3} \mathrm{H}\right]$ androstenedione (Dupont NEN) in $0.5 \mathrm{ml}$ of $50 \mathrm{mmol} / \mathrm{L}$ Tris- $\mathrm{HCl}(\mathrm{pH} \mathrm{7.5).} \mathrm{After} \mathrm{a}$ 
3 minute preincubation, the reaction was initiated by the addition of NADPH $(0.5 \mathrm{mmol})$ and carried out for 60 minutes at $37^{\circ} \mathrm{C}$. Under these conditions, the aromatase activity was linearly correlated with the amount of microsomal protein and the incubation time. The reaction was terminated by adding $3 \mathrm{ml}$ of ice-cold chloroform, followed by vigorous vortexing and brief centrifugation. The resulting aqueous layer was further extracted with $3 \mathrm{ml}$ of chloroform and then treated with $0.5 \mathrm{ml}$ of $5 \%$ activated charcoal $/ 0.5 \%$ dextran. After centrifugation of the mixture, the radioactivity of the supernatant was counted. Aromatase activity was quantified by measurement of the tritiated water released from $1 \mathrm{~b}$ $\left[{ }^{3} \mathrm{H}\right]$ androstenedione. The reaction was also performed in the presence of $10 \mathrm{mmol} / \mathrm{L}$ vorozole, a specific aromatase inhibitor, as a specificity control, and without NADPH as a background control. [30, 31]

\section{Statistical Analysis}

Aromatase mRNA levels were adjusted to those per total RNA and expressed as attomol/ng total RNA. All data were presented as the mean \pm SEM. For comparisons involving several groups, one way ANOVA was employed. For comparisons between two groups, we used unpaired t-test after Fisher's exact test. In order to examine the correlation of the two factors, the Spearman's correlation coefficient was used. A value of $\mathrm{p}<0.05$ was considered statistically significant.

\section{Results}

The results are summarized in Table 1.

\section{Immunolocalization of aromatase and 17 $\beta-H S D$ I}

Immunoreactivity of both aromatase and $17 \beta$-HSD I was detected in cytoplasms of smooth muscle cells of inferior vena cava wall positive for $\alpha$-smooth muscle action (Fig. 2A and B). 20/29 and 22/29 cases also demonstrated aromatase and 17 $\beta$-HSD I immunoreactivity, respectively, in endothelial cells positive for CD34 antigen. (Fig. 2A and B). There was a significant correlation between aromatase and $17 \beta$-HSD I LI $(p=0.078)$. There were no significant differences in aromatase or $17 \beta$-HSD I labeling index between men and women. There was no correlation between age and the labeling index when evaluating the whole group or men and women separately.

\section{Immunolocalization of $E R$}

ER immunoreactivity was detected in the nuclei of smooth muscle cells of inferior vena cava wall in 21/29 cases (Fig. 2C). Endothelial cells were immunohistochemically negative for ER. In 13 cases, more than $5 \%$ of the smooth muscle cells were immunohistochemically positive. There were no significant differences in ER LI among tissues taken from men and women. There were no correlations between age and the labeling index when evaluating the whole group or men and women separately. There were no significant correlations among aromatase, 17 $\beta$-HSD I and ER LI in the cases examined.

\section{Quantitation of aromatase $m R N A$}

Aromatase mRNA could be detected in all the cases examined. The amount of aromatase mRNA varied widely among the subjects $(101.5 \pm 25.5$ attomol/ng total RNA). Tissues from female cases $(108.7 \pm 32.1$ attomol/ng total RNA) tended to have higher levels of aromatase mRNA than those from the male cases $(89.2 \pm 44.1$ attomol/ng total RNA) but the differences did not reach statistical significances.

No significant correlation was detected between the amounts of aromatase mRNA and the age of the patients, or the labeling indices of aromatase, 17 $\beta$ HSD I and ER.

\section{Alternative utilization of multiple copies of exon $1 \mathrm{~s}$}

Alternative utilization of multiple copies of exon 1 could be evaluated in $23 / 24$ specimens. The sizes of PCR products were $327 \mathrm{bp}, 308 \mathrm{bp}$. and $355 \mathrm{bp}$ for exons 1b (I.4), 1c (I.3) and 1d (P.II), respectively. Results are summarized in Table 1 . There were 14, 7, 2 and 2 cases in which exons $1 \mathrm{~b}$ (I.4), 1c (I.3), 1d (P.II) and 1c (I.3) and 1d (P.II), respectively, were utilized as the major transcripts. The amount of aromatase mRNA $(191.1 \pm 26.3$ attomol/ng total RNA) in the cases utilizing exon 1c (I.3) and 1d (P.II) 
Table 1. Summary of Results

\begin{tabular}{|c|c|c|c|c|c|c|c|c|}
\hline \multirow[b]{2}{*}{ case } & \multirow[b]{2}{*}{ ages } & \multirow[b]{2}{*}{$\operatorname{sex}$} & \multirow{2}{*}{$\begin{array}{l}\text { arom } \\
\text { mRNA }\end{array}$} & \multirow{2}{*}{$\begin{array}{l}\text { arom } \\
\text { activity }\end{array}$} & \multicolumn{3}{|c|}{ immunohistochemistry } & \multirow{2}{*}{$\begin{array}{l}\text { alternative use } \\
\text { of exon } 1\end{array}$} \\
\hline & & & & & Arom & $17 \beta$ & & \\
\hline 1 & 15 & f & 87.2 & 769.4 & 1 & 1 & - & $1 b>1 d>1 c$ \\
\hline 2 & 37 & $\mathrm{f}$ & 48.4 & 86.2 & 1 & 1 & - & $1 b>1 d>1 c$ \\
\hline 3 & 40 & $\mathrm{f}$ & 205.6 & 459.9 & 3 & 3 & 3 & $1 b>1 d>1 c$ \\
\hline 4 & 41 & $\mathrm{f}$ & 41.5 & 324.5 & 1 & 1 & - & $1 b>1 d>1 c$ \\
\hline 5 & 48 & $\mathrm{f}$ & 18.3 & 142.8 & 2 & 2 & 1 & $1 b=1 c$ \\
\hline 6 & 51 & $\mathrm{f}$ & 32.4 & 123.7 & 2 & 3 & 1 & $1 b>1 c$ \\
\hline 7 & 56 & $\mathrm{f}$ & 75.5 & 4.1 & 3 & 3 & 2 & $1 c>1 d>1 b$ \\
\hline 8 & 60 & $\mathrm{f}$ & 357.1 & N/A & 2 & 3 & 3 & $1 c>1 b=1 d$ \\
\hline 9 & 66 & f & 456.6 & 1488.1 & 2 & 2 & 2 & $1 d>1 c>1 b$ \\
\hline 10 & 69 & $\mathrm{f}$ & 158.6 & N/A & 3 & 3 & 2 & $1 c=1 d>1 b$ \\
\hline 11 & 70 & $\mathrm{f}$ & NA & N/A & 3 & 3 & - & NA \\
\hline 12 & 70 & f & 47.4 & 147.2 & 3 & 3 & 2 & $1 c>1 d>1 b$ \\
\hline 13 & 71 & f & 67.7 & N/A & 3 & 2 & 2 & $1 b=1 c=1 d$ \\
\hline 14 & 75 & $\mathrm{f}$ & 41.9 & N/A & 3 & 3 & 1 & $1 b=1 c=1 d$ \\
\hline 15 & 75 & $\mathrm{f}$ & 42.2 & 285.8 & 3 & 3 & 1 & $1 c>1 d>1 b$ \\
\hline 16 & 77 & $\mathrm{f}$ & 19.4 & N/A & 2 & 3 & 1 & $1 b$ \\
\hline 17 & 82 & f & NA & N/A & 2 & 3 & 2 & NA \\
\hline 18 & 83 & $\mathrm{f}$ & 23.1 & 355.9 & 1 & 1 & - & $1 b=1 c>1 d$ \\
\hline 19 & 53 & $\mathrm{~m}$ & 105.7 & N/A & 3 & 3 & 2 & $1 c>1 b>1 d$ \\
\hline 20 & 58 & $\mathrm{~m}$ & 386.3 & 1201.8 & 1 & 1 & - & $1 d>1 c$ \\
\hline 21 & 60 & $\mathrm{~m}$ & NA & N/A & 2 & 3 & 3 & NA \\
\hline 22 & 66 & $\mathrm{~m}$ & 28.8 & 103.9 & 3 & 3 & 2 & $1 b$ \\
\hline 23 & 69 & $\mathrm{~m}$ & 18.9 & 215.7 & 2 & 3 & 2 & $1 b>1 c>1 d$ \\
\hline 24 & 71 & $\mathrm{~m}$ & 91.0 & N/A & 3 & 3 & 1 & $1 c=1 d$ \\
\hline 25 & 72 & $\mathrm{~m}$ & NA & N/A & 1 & 1 & 2 & NA \\
\hline 26 & 73 & $\mathrm{~m}$ & 39.4 & N/A & 3 & 3 & 1 & $1 b$ \\
\hline 27 & 74 & $\mathrm{~m}$ & 35.4 & 532.8 & 1 & 1 & - & $1 b>1 d>1 c$ \\
\hline 28 & 75 & $\mathrm{~m}$ & NA & N/A & 3 & 3 & 1 & NA \\
\hline 29 & 88 & $\mathrm{~m}$ & 8.6 & N/A & 2 & 3 & - & ND \\
\hline \multirow[t]{2}{*}{ mean } & 63.6 & & 101.5 & 416.12 & 2.52 & 2.78 & 1.76 & \\
\hline & \pm 3.00 & & \pm 25.5 & \pm 415 & \pm 0.12 & \pm 0.11 & \pm 0.15 & \\
\hline \multicolumn{9}{|l|}{ note: } \\
\hline \multirow{5}{*}{$\begin{array}{l}1 . \\
2 . \\
3 .\end{array}$} & \\
\hline & \multicolumn{8}{|c|}{ arom activity represents $\mathrm{pmol} / \mathrm{hour} / \mathrm{mg}$ protein } \\
\hline & \multicolumn{8}{|c|}{ arom: aromatase } \\
\hline & \multicolumn{8}{|c|}{$17 \beta: 17 \beta$-hydroxysteroid dehydrogenase type I } \\
\hline & \multicolumn{8}{|c|}{ ER: estrogen receptor } \\
\hline 4. & \multicolumn{8}{|c|}{ N/A: not available, ND: not done } \\
\hline 5. & \multicolumn{8}{|c|}{ Immunohistochemistry } \\
\hline & \multicolumn{8}{|c|}{$-:$ none } \\
\hline & \multicolumn{8}{|c|}{1 : positive SMC (smooth muscle cells) less than $5 \%$} \\
\hline & \multicolumn{8}{|c|}{$2:$ positive SMC $5-25 \%$} \\
\hline & \multicolumn{8}{|c|}{$3:$ positive SMC more than $25 \%$} \\
\hline
\end{tabular}

as the major transcripts ( 9 cases; $191.1 \pm 26.3$ attomol/ng total RNA) was significantly higher than the amount in the cases utilizing mainly exon $1 \mathrm{~b}\{\mathrm{I} .4\}$ (14 cases; 50.6 \pm 13.0 attomol/ng total RNA) $\{\mathbf{p}<0.001\}$. In particular, two cases which utilized exon 1d (P.II) as the major transcript (case \#9, 66 year old female and case \#20, 58 year old male) demonstrated highest amounts of aromatase mRNA 

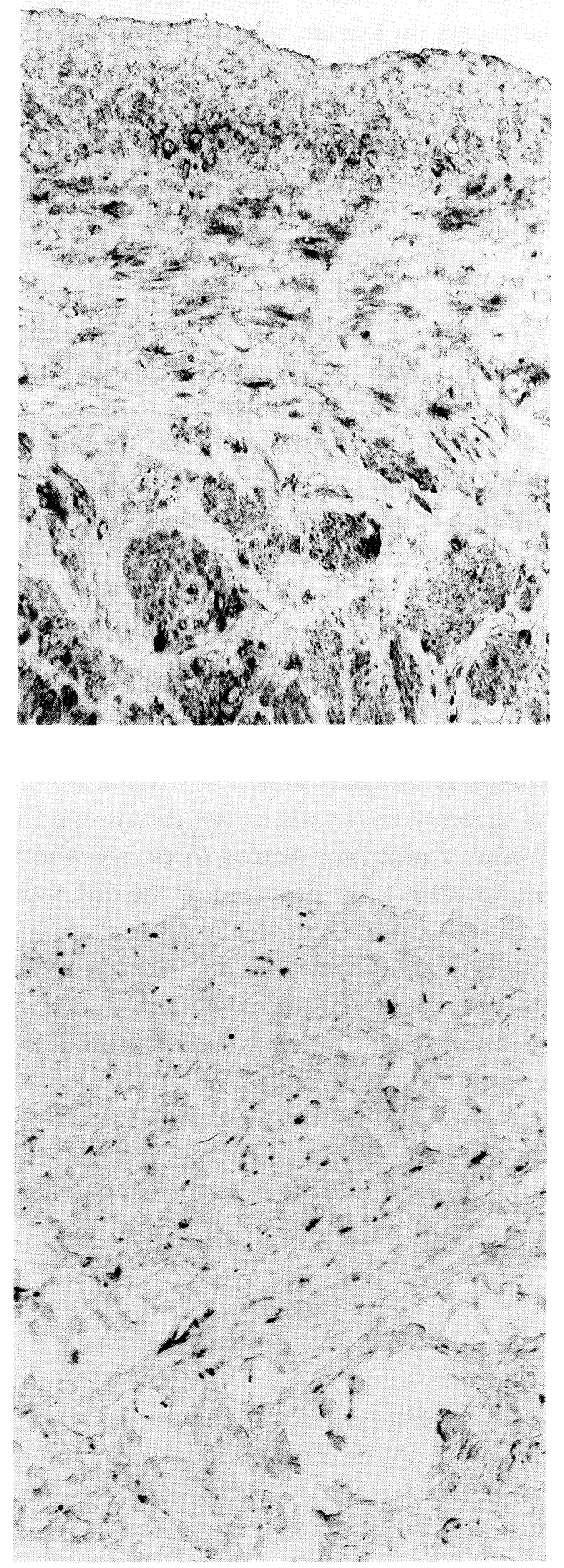

(456.6 and 386.3 attomol/ng total RNA). There were no significant differences in utilization of exon $1 \mathrm{~s}$ between men and women.

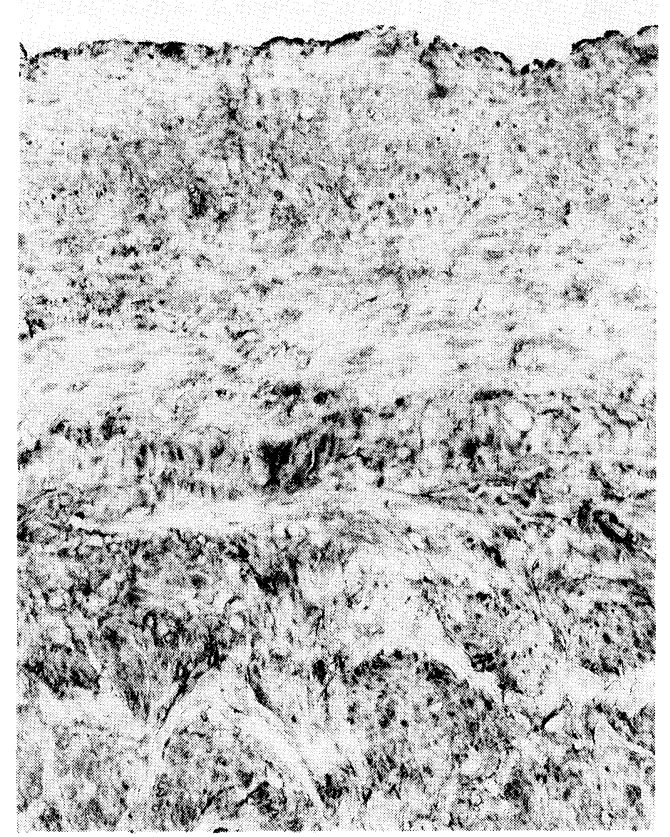

Fig. 2. Immunohistochemistry of aromatase $(\mathrm{A}, \times 150), 17 \beta$-HSD I $(\mathrm{B}, \times 100)$ and estrogen receptor $(C, \times 200)$ in a 69year-old female. (case 10 in Table 1) Aromatase and $17 \beta$-HSD I immunoreactivity were observed both in smooth muscle cells and endothelial cells. ER nuclear immunoreactivity was detected in smooth muscle cells.

\section{Aromatase activity}

Aromatase activity could be evaluated in all 15 
cases examined. The amount of aromatase activity varied widely among the subjects $(416.12 \pm 415$ $\mathrm{pmol} / \mathrm{hour} / \mathrm{mg}$ protein, $86.2-1488.1 \mathrm{pmol} / \mathrm{hour} /$ $\mathrm{mg}$ protein) but there was a significant correlation between the amounts of aromatase mRNA and activity in these 15 cases examined.

\section{Discussion}

In our present study, aromatase and $17 \beta$-HSD I immunoreactivity was detected in both smooth muscle cells and endothelial cells of inferior vena cava. In addition, aromatase activity was also detected in these tissues. These results therefore indicated that estrone is produced as a result of aromatization and is then converted to estradiol, a potent estrogen in human vena cava. In men and postmenopausal women, circulating estrogens have been considered to be mainly derived from aromatization occurring in adipocytes $[7,8]$ but the vena cava and possibly other veins, may also be considered to be important sources of circulating estrogens because of their close proximity to circulation.

Direct effects of sex steroids on human veins have been postulated by a number of investigators $[1,2,3$, $4,5,6]$. Karas et al. reported the presence of ER in smooth muscle cells of human saphenous vein, although at a low level [4] but Perrot-Applanat et al. reported that ER and its mRNA were undetectable in $80 \%$ of saphenous veins examined [6]. The results of our present study of the human vena cava revealed that ER immunoreactivity was detected in smooth muscle cells of vena cava in $21 / 29$ cases but ER immunoreactivity can be demonstrated only by means of the antigen retrieval and catalyzed signal amplification method. In addition, there were no correlations between the amounts of aromatase mRNA expression or aromatase LI and ER LI. Therefore, estrone or estradiol produced in endothelial or smooth muscle cells of vena cava may not necessarily act directly on these cells in situ. Further investigations including the analysis of newly characterized estrogen receptor beta $[32,33]$ in human veins are necessary to clarify the possible direct actions of estrogens on human vena cava and veins.

Recently, the expression of aromatase in various human tissues has been reported to be regulated by different tissue-specific factors, chiefly alternative use of exon 1 and promoters $[16,19,28]$. The results of our present study demonstrated that human vena cava tissues utilized exon 1b or I.4 (fibroblast type), exon 1c or I.3 and exon 1d or P.II (gonadal type). Switching of alternative exons 1 was proposed to result in increased aromatase expression, and possible overproduction of estrogen in situ, under the control of a new promoter $[20,21]$. In our present study, the amounts of aromatase mRNA in the cases utilizing gonadal types of exon 1, i.e., 1c (I.3) and 1d (P.II), were significantly higher than in those that used other exon 1s. In particular, two cases utilizing exon 1d (P.II) as the major transcript demonstrated the highest amounts of aromatase mRNA among the cases examined. These results demonstrated that the utilization of gonadal type exon 1 may also be involved in overproduction of aromatase in vena cava as reported in human breast carcinoma [20,21], but further studies are needed to clarify whether switching of exon 1 has occurred or the utilization of exon 1 in vena cava is genetically determined among these subjects examined. Serum estrogen levels were not available in any of the patients examined in this study because all were autopsy materials but it is interesting to postulate that individuals utilizing exon 1c (I.3) and $1 \mathrm{~d}$ (P.II) may use these exon $1 \mathrm{~s}$ in sites other than the vena cava including adipocytes and subsequently result in relatively high levels of circulating estrogens for age or sex.

\section{Acknowledgements}

This work was in part supported by a grant from the Ministry of Education, Japan and by a grant from Public Trust Haraguchi Memorial Cancer Research Fund, Tokyo, Japan.

\section{References}

1. Perrot-Applanat $\mathbf{M}$, Cohen-Solal K, Milgrom E, Finet $\mathbf{M}$ (1995) Progesterone receptor expression in human saphenous veins. Circulation 92: 2975-2983.

2. Brand FN, Dannenberg AL, Abbott RD, Kannel WB 
(1988) The epidemiology of varicose veins: the Framingham Study. Am J Prev Med 4: 96-101.

3. Gerstman BB, Piper JM, Tomita DK (1991) Oral contraceptive estrogen dose and the risk of deep venous thromboembolic disease. Am J Epidemiol 133: 32-37.

4. Karas RH, Patterson BL, Mendelsohn ME (1994) Human vascular smooth muscle cells contain functional estrogen receptor. Circulation 89: 1943-1950.

5. Losordo DW, Kearney M, Kim EA, Jekanowski J, Isner JM (1994) Variable expression of the estrogen receptor in normal and atherosclerotic coronary arteries of premenopausal women. Circulation 89: 15011510.

6. Perrot-Applanat M, Groyer-Picard MT, Garcia E, Lorenzo F, Milgrom E (1988) Immunocytochemical demonstration of estrogen and progesterone receptors in muscle cells of uterine arteries in rabbits and human. Endocrinology 123: 1511-1519.

7. Gordin JM, Siiteri PK, Macdonald PC (1973) Source of estrogen production in postmenopausal women. $J$ Clin Endocrinol Metab 36: 207-214.

8. Bulun SE, Simpson ER (1993) Competitive reverse transcription-polymerase chain reaction analysis indicates that levels of aromatase cytochrome P450 transcripts in adipose tissue of buttocks, thighs, and abdomen of women increase with advancing age. $J$ Clin Endocrinol Metab 78: 428-432.

9. Schweikert HV, Milewich L, Wilson JD (1976) Aromatization of androstenedione by cultured human fibroblasts. J Clin Endocrinol Metab 43: 785-595.

10. Frost PG, Reed MJ, James VH (1980) The aromatization of androstenedione by human adipose and liver tissue. J Steroid Biochem 13: 1427-1431.

11. Foidart A, Harada N, Balthazart J (1994) Effects of steroidal and non-steroidal aromatase inhibitors on sexual behavior and aromatase-immunoreactive cells and fibers in the quail brain. Brain Res 657: 105-123.

12. Sasano H, Uzuki M, Sawai $T$, Nagura $H$, Matsunaga G, Kashimoto O, Harada N (1997) Aromatase in human bone tissue. J Bone Miner Res 12: 1416-1423.

13. Sasano H, Frost AR, Saito R, Harada N, Poutanen M, Vihko R, Bulun SE, Silverberg SG, Nagura $H$ (1996) Aromatase and $17 \beta$-hydroxysteroid dehydrogenase type 1 in human breast carcinoma. $J$ Clin Endocrinol Metab 81: 4042-4046.

14. Sasano H, Kaga K, Sato S, Yajima A, Nagura H, Harada N (1996) Aromatase cytochrome P450 gene expression in endometrial carcinoma. Br J Cancer 74: 1541-1544.

15. Kaga K, Sasano H, Harada N, Ozaki M, Sato S, Yajima A (1996) Aromatase in human common epithelial ovarian neoplasms. Am J Pathol. 149: 4551.
16. Bulun SE, Rosenthal IM, Brodie AM, Inkster SE, Zeller WP, DiGeorge AM, Frasier SD, Kilgore MW, Simpson ER (1993) Use of tissue-specific promoters in the regulation of aromatase cytochrome P450 gene expression in human testicular and ovarian sex cord tumors, as well as in normal fetal and adult gonads. $J$ Clin Endocrinol Metab 77: 1616-1621.

17. Bayard F, Clamens S, Delsol G, Blaes N, Maret A, Faye J-C (1995) Oestrogen synthesis, oestrogen metabolism and functional oestrogen receptors in bovine aortic endotyhelial cells. Ciba Foundation Symposium 191: 122-138.

18. Bayard F, Clamens S, Delsol G, Meggetto F, Blaes N, Delsol G, Faye J-C (1995) Estrogen synthesis, estrogen metabolism, and functional estrogen receptors in rat arterial smooth muscle cells in culture. Endocrinology 136: 1523-1529.

19. Mahendroo MS, Means GD, Mendelson CR, Simpson ER (1991) Tissue-specific expression of human P450arom: the promoter responsible for expression in adipose tissue is different from that utilized in placenta. $J$ Biol Chem 266: 11276-11281.

20. Utsumi T, Harada N, Maruta M, Takagi Y (1996) Presence of alternatively splices transcripts of aromatase gene in human breast cancer. J Clin Endocrinol Metab. 81: 2344-2349.

21. Agarwal VR, Bulun SE, Leitch M, Rohrich R, Simpson ER (1961) Use of alternative promoters to express the aromatase cytochrome P450 (CYP19) gene in breast adipose tissues of cancer-free and breast cancer patients. J Clin Endocrinol Metab 81: 3843-3849.

22. Nokelainen $\mathbf{P}$, Puranen $T$, Peltoketo $H$, Orava $M$, Vihoko P, Vihko R (1996) molecular cloning of mouse $17 \beta$-hydroxysteroid dehydrogenase type 1 and characterization of enzyme activity. Eur J Biochem 236: 482-490.

23. Harada N (1988) Novel properties of human placental aromatase as cytochrome P450: purification and characterization of a unique form of aromatase. $J$ Biochem 103: 106-112.

24. Poutanen M, Isomaa V, Lehto VP, Vihko R (1992) Immunological analysis of 17 beta- hydroxysteroid dehydrogenase in benign and malignant human breast tissue. Int J Cancer. 50: 386-390.

25. Sasano H (1994) Functional pathology of human ovarian steroidogenesis, normal cycling ovary and steroid producing neoplasms. Endo Pathol 5: 81-89.

26. Sasano H, Kimura M, Shizawa S, Kimura, Nagura $\mathbf{H}$ (1996) Aromatase and steroid receptors in gynecomastia and male breast carcinoma: An immunohistochemical study. J Clin Endocrinol Metab 81: 30633067.

27. Watanabe K, Sasano H, Harada N, Ozaki M, Niikura H, Sato S, Yajima A (1995) Aromatase in human 
endometrial carcinoma and hyperplasia: Immunohistochemical, in situ hybridization, and biochemical studies. Am J Pathol 146: 491-500.

28. Harada N, Utsumi T, Takagi Y (1993) Tissue-specific expression of the human aromatase cytochrome p-450 gene by alternative of tissue-specific exons 1 in carcinogenesis. Proc Natl Acad Sci USA 90: 11312 $-11316$.

29. Chirgwin JM, Przybla AE, MacDonald KJ, Utter WJ (1979) Isolation of biologically active ribonucleic acid from sources enriched in ribonuclease. Biochemistry 18: 5294-5299.

30. Thompson EA, Siiteri PK (1974) Utilization of oxygen and reduced nicotinamide adenine dinucleotide phosphate by human placental microsomes during aromatization of androstenedione. J Biol Chem 249: 5364-5372.
31. Kaga K, Sasano H, Harada N, Ozaki M, Sato S, Yajima A (1996) Aromatase in human common epithelial ovarian neoplasms. Am J Pathol 149: 4551.

32. Enmark E, Pelto-Huikko M, Grandien K, Lagercrantz S, Lagercrantz J, Fried G, Nordenskjold M, Gustafsson JA (1997) Human estrogen receptor betagene structure, chromosomal localization, and expression pattern. J Clin Endocrinol Metab 82: 42584265.

33. Arts J, Kuiper GG, Janssen JM, Gustafsson JA, Lowik CW, Pols HA, van Leeuwen JP (1997) Differential expression of estrogen receptors alpha and beta mRNA during differentiation of human osteoblast SV-HFO cells. Endocrinology 138: 5067 -5070 . 